\title{
Design and Analysis of a Modified-atmosphere Package for Minimally Processed Romaine Lettuce
}

\author{
Kevin I. Segall and Martin G. Scanlon \\ Department of Food Science, University of Manitoba, Winnipeg, MB R3T 2N2, Canada
}

\begin{abstract}
Additional index words. Lactuca sativa, respiration, closed system, steady state, oxygen permeability, senescence, phenolic oxidation, microbiology, color analysis

Abstract. The first goal of this study was to determine the packaging film $\mathrm{O}_{2}$ permeability required to maintain a steadystate $\mathrm{O}_{2}$ concentration of $3 \%$ in modified-atmosphere packaging (MAP) of minimally processed romaine lettuce (Lactuca sativa $\mathbf{L}$.). The second goal of the study was to determine the extent to which MAP could preserve lettuce quality and consequently extend product shelf life. Oxygen consumption rates of commercially prepared lettuce samples were determined in a closed system for each of three atmospheres $\left(3 \% \mathrm{O}_{2}\right.$ combined with either $6 \%, 10 \%$, or $\left.14 \% \mathrm{CO}_{2}\right)$. Enzymatic, quadratic, and linear mathematical models were compared to determine which best described the respiratory data. The linear model was the most suitable and was used to predict the $\mathrm{O}_{2}$ consumption rate of the minimally processed romaine lettuce under the desired package headspace gas concentrations. The predicted $\mathrm{O}_{2}$ consumption rate was used to calculate the necessary $\mathrm{O}_{2}$ permeability for the packaging film. Packages $(21.6 \times 25.4 \mathrm{~cm})$ were constructed from a polypropylene-polyethylene-laminate film with the appropriate $\mathrm{O}_{2}$ permeability. Packaged samples were stored under three modified atmospheres (MAs) $\left(3 \% \mathrm{O}_{2}\right.$ combined with either $6 \%, 10 \%$, or $\left.14 \% \mathrm{CO}_{2}\right)$ for 20 days, and headspace gas concentrations, lettuce appearance, and color were evaluated every other day. Growth of pectinolytic and lactic acid bacteria was also studied. The $\mathrm{O}_{2}$ consumption rate of the lettuce decreased with increasing $\mathrm{CO}_{2}$ levels. The $\mathrm{O}_{2}$ levels in the MA packages equilibrated at $7 \%$ to $11 \%$. Compared to a control atmosphere of air, MAP delayed the development of tissue discoloration. Preliminary results indicated no effect of MAP on microbial growth. Of the three $\mathrm{CO}_{2}$ levels, $10 \%$ was slightly more effective than $6 \%$ and $14 \%$. Critical choice of packaging permeabilities combined with MAP maintained the quality of minimally processed romaine lettuce and thereby increased shelf life by about $50 \%$.
\end{abstract}

Minimally processed romaine lettuce is a product that offers convenience and quality. However, the physiological stresses that the lettuce is subjected to during processing and storage limit its shelf life. These stresses include deteriorative reactions of wounded or senescing leaf tissue, decay caused by the growth of microorganisms, and water loss from the tissue (King and Bolin, 1989). Methods currently used for preservation include low-temperature storage and packaging in a plastic film. Although these methods work reasonably well, it is believed that an increase in shelf life would result from storing the lettuce under a modified atmosphere (MA), as for other produce (Kader et al., 1989).

MA storage would aid in preventing deteriorative reactions and microbial growth but would not affect water loss. Modified atmosphere packaging (MAP) of minimally processed iceberg lettuce (Ballantyne et al., 1988; McDonald et al., 1990; Priepke et al., 1976) and whole heads of romaine lettuce (Aharoni and BenYehoshua, 1973; Lipton, 1987) has been attempted, but there are no published reports of the effect of MAP on minimally processed romaine lettuce.

When a MA package is flushed with the ideal gas levels for preserving a commodity, it is preferable if gas levels remain close to their initial values (i.e., maintain steady state conditions). Technically, this would result in controlled atmosphere (CA) rather than MAP (Brecht, 1980). To maintain the desired gas levels within the package, two factors must be considered. First, the produce in the package is continually respiring and consuming $\mathrm{O}_{2}$ while producing $\mathrm{CO}_{2}$. Second, $\mathrm{O}_{2}$ will diffuse into the bag and $\mathrm{CO}_{2}$

Received for publication 9 June 1995. Accepted for publication 12 Feb. 1996. This research was made possible by the support of the Univ. of Manitoba, the Natural Sciences and Engineering Research Council of Canada, Atomic Energy Canada Ltd. (J. Borsa), Supreme Produce (R. Scheuer and G. McTavish), and Winpak (E. Sachvie). We are also grateful to G. Blank for helpful discussions and assistance with the microbiological assays. The cost of publishing this paper was defrayed in part by the payment of page charges. Under postal regulations, this paper therefore must be hereby marked advertisement solely to indicate this fact. will diffuse out. This occurs because the package contains low levels of $\mathrm{O}_{2}$ and high levels of $\mathrm{CO}_{2}$, and the atmosphere outside the package contains $21 \% \mathrm{O}_{2}$ and trace levels of $\mathrm{CO}_{2}$. To control the atmosphere within the package successfully, the permeability of the packaging film must be selected such that the rate of $\mathrm{O}_{2}$ diffusion into the package equals the rate of $\mathrm{O}_{2}$ consumption by the commodity $\left(\mathrm{KO}_{2}\right)$. Similarly, the rate of $\mathrm{CO}_{2}$ efflux should correspond to the rate of respiratory $\mathrm{CO}_{2}$ production $\left(\mathrm{ECO}_{2}\right)$.

Respiration rate is determined by measuring the consumption of $\mathrm{O}_{2}$ or the generation of $\mathrm{CO}_{2}$ over time (Kays, 1991). This may be done in a closed system in which the commodity is sealed in an air-tight container and samples of the atmosphere are removed regularly. As there is no passage of gases, the $\mathrm{O}_{2}$ levels are continuously dropping while the $\mathrm{CO}_{2}$ levels are continuously increasing. The result is a further inhibition of respiration until the respiration rate reaches equilibrium. Plotting respiration rate versus the corresponding gas concentrations allows prediction of the respiration rate at the desired $\mathrm{O}_{2}$ and $\mathrm{CO}_{2}$ concentrations (Lee, 1986).

The form of the mathematical model that best predicts respiration behavior is a matter of debate. Some researchers have argued that the presence of $\mathrm{CO}_{2}$ does not significantly affect the rate of $\mathrm{O}_{2}$ consumption and that, for the sake of simplicity, the model can neglect the presence of $\mathrm{CO}_{2}$ (Andrich et al., 1991; Cameron et al., 1989, 1994; Gong and Corey, 1994; Joles et al., 1994; Jurin and Karel, 1963; Lopez-Briones et al., 1993). However, other researchers have shown that the $\mathrm{KO}_{2}$ of a given commodity depends on the concentration of $\mathrm{CO}_{2}$ in the atmosphere (Herner, 1987). Several models have been developed that incorporate the effect of $\mathrm{CO}_{2}$. These models can be classified based on the mathematical functions used: enzymatic (Haggar et al., 1992; Lee et al., 1991, 1994; Yam et al., 1993), quadratic (Lee, 1986), or linear (Hayakawa et al., 1975).

Based on a survey of the literature (Herner, 1987), three experimental atmospheres were chosen for the MAP of minimally 
processed romaine lettuce: $6 \%, 10 \%$, or $14 \% \mathrm{CO}_{2}$, each combined with $3 \% \mathrm{O}_{2}(6 / 3,10 / 3$, and $14 / 3)$ and the balance $\mathrm{N}_{2}$. Respiration studies were conducted, and models incorporating the effect of $\mathrm{O}_{2}$ and $\mathrm{CO}_{2}$ concentrations (enzymatic, quadratic, and linear) were all fitted to the $\mathrm{O}_{2}$ consumption data. The most suitable model was used for predicting the $\mathrm{O}_{2}$ consumption rate under the desired atmospheric conditions. Oxygen permeability required of the package to maintain an $\mathrm{O}_{2}$ concentration of $3 \%$ within a package of minimally processed romaine lettuce was then calculated based on the predicted $\mathrm{O}_{2}$ consumption rate.

Commercially prepared minimally processed romaine lettuce was packaged under the three MAs $(6 / 3,10 / 3,14 / 3)$ in pouches constructed from a film that matched the required $\mathrm{O}_{2}$ permeability. Shelf-life extension was quantified by quality evaluation studies of lettuce appearance (color and the presence of defects) and microbiology (growth of pectinolytic and lactic acid bacteria). In addition, package headspace gas composition was monitored for the potential development of anaerobiosis.

\section{Materials and Methods}

Plant material. Minimally processed romaine lettuce (cultivar unknown) was obtained from a local vegetable processor (Supreme Produce, Winnipeg, Man.). Its temperature was $2{ }^{\circ} \mathrm{C}$, and it was used immediately after processing. The respiration and packaging portions of the study were performed twice each, each time using different batches of lettuce obtained from the processor. Therefore, seasonal, and possibly cultivar and geographical, differences were expected.

$M A s$. Three premixed gas cylinders were purchased from Linde (Union Carbide, Toronto, Ont.) that contained the MAs to be tested $\left(6 \%, 10 \%\right.$, or $14 \% \mathrm{CO}_{2}$, each with $3 \% \mathrm{O}_{2}$ and the balance $\left.\mathrm{N}_{2}\right)$; they were certified for accuracy by Linde. Respiration jars and MA packages were filled directly from these cylinders.

Headspace analysis. Headspace gases were analyzed using a gas chromatograph equipped with a thermal conductivity detector and a CTR 1 column (Alltech Associates Inc., Deerfield, Ill.) (Haggar et al., 1992; Yam et al., 1993). Flow rate of He carrier gas was $60 \mathrm{~mL} \cdot \mathrm{min}^{-1}$. Column and injector temperatures were $30^{\circ} \mathrm{C}$. Calibration consisted of five injections of a composite mixture containing $10 \% \mathrm{CO}_{2} / 3 \% \mathrm{O}_{2} / 87 \% \mathrm{~N}_{2}$. Gas concentrations in test samples were determined based on peak area and calculated via the corrected area normalization method using an integrator.

Oxygen consumption rate determination. To determine the respiration rate, samples of processed lettuce $(30 \mathrm{~g})$ were placed in each of twelve 910-mL glass jars with tight-fitting lids equipped with a rubber sampling port. Before sealing, jars were flushed with the premixed MAs directly from gas cylinders. Three jars were flushed for each of the three MAs, resulting in nine jars. In addition, three jars were sealed with an ambient atmosphere $\left(21 \% \mathrm{O}_{2}\right.$, trace $\mathrm{CO}_{2}$, balance mainly $\mathrm{N}_{2}$ ). All 12 jars were then stored at $3{ }^{\circ} \mathrm{C}$. Each day, gas samples were withdrawn from each jar and analyzed in triplicate. The experiment continued until the $\mathrm{O}_{2}$ concentration reached a plateau. Respiration rate, as $\mathrm{O}_{2}$ consumption $\left(\mathrm{KO}_{2}\right)$ in $\mathrm{mL} \cdot \mathrm{kg}^{-1} \cdot \mathrm{h}^{-1}$ at a given $\mathrm{O}_{2}$ level and $\mathrm{CO}_{2}$ level, was then calculated according to Kays (1991):

$$
\mathrm{KO}_{2}=\left(\Delta \% \mathrm{O}_{2} \times 10\right) \mathrm{V} /(\mathrm{W} \mathrm{t})
$$

where $\Delta \% \mathrm{O}_{2}=$ change in oxygen concentration $(\%), \mathrm{V}=$ free space volume of container $(\mathrm{L}), \mathrm{W}=$ product weight $(\mathrm{kg})$, and $\mathrm{t}=$ time container is closed (h).

Mathematical modelling. Three models were fitted to the respiration data. The first model was an enzymatic model that has been used on a variety of commodities (Haggar et al. 1992; Lee et al., 1991, 1994; Yam et al., 1993):

$$
1 / \mathrm{KO}_{2}=\mathrm{b}+\mathrm{m}_{1}\left(1 /\left[\mathrm{O}_{2}\right]\right)+\mathrm{m}_{2}\left[\mathrm{CO}_{2}\right]
$$

where $\mathrm{b}=$ constant and $\mathrm{m}_{\mathrm{x}}=$ parameter.

The second model was the quadratic model of Lee (1986):

$$
\begin{aligned}
& \mathrm{KO}_{2}=\mathrm{b}+\mathrm{m}_{1}\left[\mathrm{CO}_{2}\right]+\mathrm{m}_{2}\left[\mathrm{O}_{2}\right]+\mathrm{m}_{3}\left[\mathrm{CO}_{2}\right]\left[\mathrm{O}_{2}\right] \\
& +\mathrm{m}_{4}\left[\mathrm{CO}_{2}\right]^{2}+\mathrm{m}_{5}\left[\mathrm{O}_{2}\right]^{2}
\end{aligned}
$$

The third model was a simple linear regression (Hayakawa et al., 1975):

$$
\mathrm{KO}_{2}=\mathrm{b}+\mathrm{m}_{1}\left[\mathrm{O}_{2}\right]+\mathrm{m}_{2}\left[\mathrm{CO}_{2}\right]
$$

\begin{tabular}{|c|c|c|c|c|c|c|}
\hline \multirow[b]{2}{*}{ Day } & \multicolumn{2}{|c|}{$\mathrm{O}_{2}(\%)$} & \multicolumn{2}{|c|}{$\mathrm{CO}_{2}(\%)$} & \multicolumn{2}{|c|}{$\mathrm{KO}_{2}\left(\mathrm{ml} \cdot \mathrm{kg}^{-1} \cdot \mathrm{h}^{-1}\right)$} \\
\hline & Run 1 & Run 2 & Run 1 & Run 2 & Run 1 & Run 2 \\
\hline 0 & 3.38 & 3.07 & 6.08 & 6.28 & 8.92 & 6.61 \\
\hline 1 & 2.83 & 2.55 & 6.66 & 6.81 & 5.53 & 6.73 \\
\hline 2 & 2.47 & 2.02 & 7.10 & 7.30 & 2.75 & 6.22 \\
\hline 3 & 1.98 & 1.54 & 7.53 & 7.89 & 8.50 & 4.82 \\
\hline 4 & 1.56 & 1.20 & 7.92 & 8.41 & 1.25 & 2.90 \\
\hline 5 & 1.41 & 0.87 & 8.17 & 8.66 & 2.44 & 5.77 \\
\hline 6 & 1.34 & 0.63 & 8.37 & 9.04 & -0.99 & 0.44 \\
\hline 7 & 1.18 & 0.67 & 8.60 & 9.59 & 4.68 & -1.58 \\
\hline 8 & 0.87 & & 8.89 & & 2.72 & \\
\hline 9 & 0.74 & & 9.27 & & 0.16 & \\
\hline 10 & 0.65 & & 9.72 & & 2.06 & \\
\hline 11 & 0.54 & & 10.14 & & 0.49 & \\
\hline 12 & 0.55 & & 10.52 & & -0.81 & \\
\hline 13 & 0.52 & & 10.93 & & 1.30 & \\
\hline 14 & 0.48 & & 11.35 & & -0.36 & \\
\hline
\end{tabular}

Predicted $\mathrm{KO}_{2}$ values were then used to determine the $\mathrm{O}_{2}$ permeance $\left(\mathrm{P}^{\prime} \mathrm{O}_{2}\right)$ of the package that would be necessary to

Table 1. Oxygen consumption rate with changes in headspace gas concentrations for a closed system (initial atmosphere of $6 \%$ $\mathrm{CO}_{2} / 3 \% \mathrm{O}_{2} / 91 \% \mathrm{~N}_{2}$ ). Each data point represents the average of three replicate analyses. 
maintain the package $\mathrm{O}_{2}$ concentration at $3 \%$ (Lee, 1986).

$$
\mathrm{P}^{\prime} \mathrm{O}_{2}=\mathrm{KO}_{2} \mathrm{~W} /\left[\left(21278.3-\mathrm{PO}_{2}\right) \mathrm{A}\right]
$$

where $\mathrm{P}^{\prime} \mathrm{O}_{2}=$ oxygen permeance, i.e., permeability, through package of specified thickness $\left(\mathrm{cm}^{3} \cdot \mathrm{m}^{-2} \cdot \mathrm{Pa}^{-1} \cdot \mathrm{h}^{-1}\right), \mathrm{PO}_{2}=$ partial pressure of oxygen in package $(\mathrm{Pa})$, and $\mathrm{A}=$ package surface area $\left(\mathrm{m}^{2}\right)$.

Packaging material. Packages were constructed from polyethylene-polypropylene-laminated roll stock (OPE 1250) obtained from a local plastics manufacturer (Winpak, Winnipeg). At $4{ }^{\circ} \mathrm{C}$, the permeance of the pouches to $\mathrm{O}_{2}$ was $0.01 \mathrm{~cm}^{3} \cdot \mathrm{m}^{-2} \mathrm{~Pa}^{-1} \cdot \mathrm{d}^{-1}$ and $\mathrm{CO}_{2}$ permeability was 3 to 5 times greater than $\mathrm{O}_{2}$ permeability. Water vapor permeance was $7.5 \mathrm{~g} \cdot \mathrm{m}^{-2} \cdot \mathrm{d}^{-1}$ at $37.8^{\circ} \mathrm{C}$ and $90 \%$ relative humidity. Film thickness was $72 \mu \mathrm{m}$ (all figures supplied by Winpak). To facilitate multiple gas samplings from the packages, a $1.25-\mathrm{cm}$-diameter silicon rubber septum was affixed to each package with adhesive.

$M A P$. Two trials were performed. Each trial of the packaging experiment was identical, except that the microbiological analysis was excluded from trial II.

Ninety lettuce samples (100 g each) were placed in the laminated bags. Before thermal sealing, the pouches were evacuated and then back flushed with one of the premixed gas mixtures using a MAP machine (GM2002; Bizerba Canada, Mississauga, Ont.). Thirty control samples (350 g) were sealed in air as currently performed by Supreme Produce. All packages were then stored at $3{ }^{\circ} \mathrm{C}$.

Every other day, three packages were analyzed from each treatment group. Gas samples were removed from each package in triplicate and analyzed. After headspace analysis was completed, packages were opened and lettuce samples were removed and analyzed for appearance and color. Every fourth day, lettuce samples were analyzed for pectinolytic and lactic acid bacteria.

Color analysis. A HunterLab D25L-2 color-difference meter (HunterLab, Fairfax, Va.) was used to assess lettuce color, generating values of $\mathrm{L}(100=$ bright, $0=$ dark $)$ and a (positive $=$ red, negative $=$ green $)($ Hunter, 1975). Analysis consisted of filling the HunterLab cell with loosely packed pieces of lettuce, taking the measurement, and then emptying and repacking the cell. This was repeated five times per sample and the values were averaged.

Microbiology. Lettuce samples (11 g) were homogenized and appropriate decimal dilutions were made in $0.1 \%$ peptone solution. For pectinolytic bacteria, $0.1-\mathrm{mL}$ aliquots were spread-plated in duplicate on the yeast extract-enriched pectin mineral media of Hankin et al. (1971). Plates were incubated for 2 days at $32^{\circ} \mathrm{C}$. Visualization of pectinolytic colonies was accomplished by identifying clear zones surrounding colonies that developed $10 \mathrm{~min}$ after flooding the plate with a $1 \%(\mathrm{w} / \mathrm{v})$ solution of hexadecyltrimethylammoniumbromide (Sigma Chemical Co., St. Louis) (Hankin et al., 1971). For lactic acid bacteria, 0.1-mL aliquots were then pour-plated using MRS medium (Becton-Dickinson Co., Cockeysville, $\mathrm{Md}$.) in duplicate. Plates were incubated aerobically for 2 days at $32{ }^{\circ} \mathrm{C}$ and counted (Garg et al., 1990).

Appearance. Visual quality of each lettuce sample was assessed using a subjective scale derived from that of Kader et al. (1973). An individual examiner assigned the lettuce samples scores between 0 and 9, with $0=$ essentially free from defects, $5=$ lower limit of sales appeal, and $9=$ extremely poor. In all cases the visual quality assessment was based on a 100-g sample of lettuce removed from the bag and spread out.

Statistical analyses. All statistical analyses were performed on a computer (9000/380; Hewlett Packard, Palo Alto, Calif.) using SAS 6.07 statistical software (SAS Institute, Cary, N.C.)

The goodness of fit for the enzymatic and linear respiration models was assessed using Proc REG. Proc RSREG was used for the quadratic model.

As quality measurements for packaged samples were taken on different days for different atmospheres (control and $6 / 3$ on day 1 , $10 / 3$ and $14 / 3$ on day 2 , and so on), it was impossible to compare quality scores directly; any values to be compared must come from the same day. Fitting a model to the data over time allowed the calculation of predicted values for those days on which no measurements were taken. As it was impractical to compare all treatments at every single time point, 7 specified days were selected to be the reference points $(1,4,7,11,14,17$, and 20). These days were selected to encompass the entire time frame of the experiment and incorporate even and odd days.

To generate the predicted values, an appropriate model had to be fitted to the data. The first model attempted in all cases was a linear model using Proc GLM. Residual analysis determined the suitability of the linear model to the data (Neter et al., 1990). In cases where a linear fit was not acceptable, a nonlinear, quadratic

Table 2. Oxygen consumption rate with changes in headspace gas concentrations for a closed system (initial atmosphere of $10 \%$ $\mathrm{CO}_{2} / 3 \% \mathrm{O}_{2} / 87 \% \mathrm{~N}_{2}$ ). Each data point represents the average of three replicate analyses.

\begin{tabular}{|c|c|c|c|c|c|c|}
\hline \multirow[b]{2}{*}{ Day } & \multicolumn{2}{|c|}{$\mathrm{O}_{2}(\%)$} & \multicolumn{2}{|c|}{$\mathrm{CO}_{2}(\%)$} & \multicolumn{2}{|c|}{$\mathrm{KO}_{2}\left(\mathrm{ml} \cdot \mathrm{kg}^{-1} \cdot \mathrm{h}^{-1}\right)$} \\
\hline & Run 1 & Run 2 & Run 1 & Run 2 & Run 1 & Run 2 \\
\hline 0 & 3.05 & 2.83 & 9.97 & 10.13 & 8.81 & 6.90 \\
\hline 1 & 2.56 & 2.32 & 10.54 & 10.54 & 4.25 & 6.07 \\
\hline 2 & 2.16 & 1.80 & 11.02 & 11.02 & 4.44 & 6.69 \\
\hline 3 & 1.62 & 1.30 & 11.52 & 11.75 & 8.50 & 5.20 \\
\hline 4 & 1.19 & 0.96 & 11.94 & 12.25 & 2.08 & 2.52 \\
\hline 5 & 1.06 & 0.72 & 12.24 & 12.47 & 1.07 & 3.56 \\
\hline 6 & 1.02 & 0.58 & 12.59 & 12.89 & -0.23 & 0.09 \\
\hline 7 & 0.90 & 0.62 & 12.93 & 13.40 & 2.93 & -1.05 \\
\hline 8 & 0.68 & & 13.28 & & 2.01 & \\
\hline 9 & 0.63 & & 13.77 & & -0.77 & \\
\hline 10 & 0.58 & & 14.33 & & 2.02 & \\
\hline 11 & 0.48 & & 14.78 & & 0.25 & \\
\hline 12 & 0.48 & & 15.19 & & -0.16 & \\
\hline 13 & 0.45 & & 15.61 & & 0.72 & \\
\hline 14 & 0.44 & & 16.06 & & -0.38 & \\
\hline
\end{tabular}


fit was executed using Proc NLIN. Both of these procedures provided the predicted values for the 7 specified days as well as $95 \%$ confidence intervals for the predicted values. Two treatments were considered significantly different when there was no overlapping of their confidence intervals. All figures are shown with curves as fitted by SAS.

\section{Results and Discussion}

Headspace analyses. The headspace gas concentrations for the processed lettuce samples flushed with the three experimental MAs are shown in Tables 1 to 3. Jars containing an atmosphere of air were also monitored but the data were not used to predict the desired package $\mathrm{O}_{2}$ permeability (Table 4). Nevertheless, these latter jars served to illustrate that the respiration rate of the lettuce was slowed by the MAs.

The entire experiment was performed twice using samples taken from separate batches of lettuce processed by Supreme Produce in an attempt to increase the accuracy of the calculations. The batch of lettuce in run 2 depleted its headspace $\mathrm{O}_{2}$ several days faster than that of run 1. Possible explanations for the faster respiration rate of the second batch of tissue was that it had undergone more tissue damage in the course of processing (Rolle and Chism, 1987). It was interesting to note that $\mathrm{CO}_{2}$ production did not slow down as much as $\mathrm{O}_{2}$ consumption, suggesting that the respiratory quotient of the tissue was not equal to one. It was likely that $\mathrm{CO}_{2}$ was being liberated not only by aerobic respiration but also by anaerobic respiration when the $\mathrm{O}_{2}$ concentration decreased below the tolerance level of the tissue (Weichmann, 1987).

Mathematical modelling. As the quadratic model can be thought of as the linear model with an added quadratic component, the linear function was first compared directly to the enzymatic method. As can be seen in Table 5, the linear model provided a better fit than the enzymatic model in all cases. This was likely due to the fact that the enzymatic model is valid only for aerobic respiration and gas compositions are not well predicted when the $\mathrm{O}_{2}$ concentration is low (Lee at al., 1991).

The fits achieved in run 2 were better than run 1, probably because run 1 had been extended longer. Therefore, the greater contribution of anaerobic respiration had a negative effect on the goodness of fit for both models.
Comparison of the linear model with the quadratic model revealed that incorporating the quadratic functions and the crossproduct did not provide a statistically significant improvement to the goodness of fit. The unsuitability of the quadratic model was likely attributed to the fact that it was developed with an ambient atmosphere (Lee, 1986) and not one of elevated $\mathrm{CO}_{2}$ and lowered $\mathrm{O}_{2}$ levels. The error associated with the fit of the linear model was thought to be due to the heterogeneity of the tissue as well as the contribution of anaerobic respiration.

Estimates of the constant $\mathrm{b}$ and the parameters $\mathrm{m}_{1}$ and $\mathrm{m}_{2}$, provided by the linear model, were averaged over runs 1 and 2 to provide linear equations that predicted the $\mathrm{O}_{2}$ consumption rate under each experimental atmosphere:

$$
\begin{aligned}
& \text { for } 6 / 3 \mathrm{KO}_{2}=37.65-2.18\left[\mathrm{O}_{2}\right]-3.83\left[\mathrm{CO}_{2}\right] \\
& \text { for } 10 / 3 \mathrm{KO}_{2}=36.29-0.68\left[\mathrm{O}_{2}\right]-2.70\left[\mathrm{CO}_{2}\right] \\
& \text { for } 14 / 3 \mathrm{KO}_{2}=26.48+0.72\left[\mathrm{O}_{2}\right]-1.54\left[\mathrm{CO}_{2}\right]
\end{aligned}
$$

Substituting the gas concentrations into these equations provided the predicted $\mathrm{O}_{2}$ consumption rates of $8.13,7.25$, and 7.08 $\mathrm{mL} \cdot \mathrm{kg}^{-1} \cdot \mathrm{h}^{-1}$ for the $6 / 3,10 / 3$, and $14 / 3$ atmospheres, respectively.

These results demonstrate some reduction in $\mathrm{O}_{2}$ consumption rate with increasing $\mathrm{CO}_{2}$ levels. This agrees with the findings of other workers, such as Lee et al. (1991) and Henig and Gilbert (1975), and justifies the inclusion of $\mathrm{CO}_{2}$ in the respiration model.

Although it would have been the ideal situation, it was not feasible to generate different types of packages for each MA. Therefore, the predicted $\mathrm{KO}_{2}$ values were averaged across the different atmospheres to provide an average $\mathrm{KO}_{2}$ of $7.49 \mathrm{~mL} \cdot \mathrm{kg}^{-1} \cdot \mathrm{h}^{-1}$.

Calculation of $\mathrm{O}_{2}$ permeability. To get an idea of the permeability required of the package, calculations were performed using a dummy size of $0.20 \mathrm{~m}$ square that was sufficient to contain $100 \mathrm{~g}$ of lettuce. The permeance value calculated from Eq. [5] using the dummy package size was then given to plastics manufacturer Winpak, and they supplied a polypropylene-polyethylene-laminated film that provided their closest match $\left(\mathrm{P}^{\prime} \mathrm{O}_{2}=0.00042\right.$ $\mathrm{cm}^{3} \cdot \mathrm{m}^{-2} \cdot \mathrm{Pa}^{-1 \cdot} \mathrm{h}^{-1}$ at $4^{\circ} \mathrm{C}$ ) to the permeance figure. Next, the area of the package was manipulated to bring the rate of $\mathrm{O}_{2}$ influx as close to $0.749 \mathrm{~mL} \cdot \mathrm{h}^{-1}$ as possible. It was decided that MAP should supply

\begin{tabular}{|c|c|c|c|c|c|c|}
\hline \multirow[b]{2}{*}{ Day } & \multicolumn{2}{|c|}{$\mathrm{O}_{2}(\%)$} & \multicolumn{2}{|c|}{$\mathrm{CO}_{2}(\%)$} & \multicolumn{2}{|c|}{$\mathrm{KO}_{2}\left(\mathrm{ml} \cdot \mathrm{kg}^{-1} \cdot \mathrm{h}^{-1}\right)$} \\
\hline & Run 1 & Run 2 & Run 1 & Run 2 & Run 1 & Run 2 \\
\hline 0 & 3.27 & 2.96 & 13.50 & 13.84 & 7.11 & 8.48 \\
\hline 1 & 2.78 & 2.31 & 14.07 & 14.31 & 5.38 & 7.84 \\
\hline 2 & 2.39 & 1.73 & 14.54 & 14.84 & 3.44 & 6.16 \\
\hline 3 & 1.91 & 1.22 & 15.06 & 15.63 & 7.93 & 5.72 \\
\hline 4 & 1.41 & 0.90 & 15.56 & 16.23 & 3.63 & 1.27 \\
\hline 5 & 1.34 & 0.69 & 15.65 & 16.56 & -1.96 & 4.42 \\
\hline 6 & 1.41 & 0.52 & 15.79 & 17.20 & 0.51 & -0.02 \\
\hline 7 & 1.20 & 0.57 & 16.19 & 17.80 & 4.53 & -1.18 \\
\hline 8 & 0.89 & & 16.54 & & 2.74 & \\
\hline 9 & 0.87 & & 16.97 & & -2.27 & \\
\hline 10 & 0.80 & & 17.53 & & 3.76 & \\
\hline 11 & 0.59 & & 18.09 & & 1.13 & \\
\hline 12 & 0.60 & & 18.43 & & -1.51 & \\
\hline 13 & 0.62 & & 18.67 & & 0.63 & \\
\hline 14 & 0.55 & & 19.12 & & 1.04 & \\
\hline
\end{tabular}

Table 3. Oxygen consumption rate with changes in headspace gas concentrations for a closed system (initial atmosphere of $14 \%$ $\mathrm{CO}_{2} / 3 \% \mathrm{O}_{2} / 83 \% \mathrm{~N}_{2}$ ). Each data point represents the average of three replicate analyses. 
Table 4. Oxygen consumption rate with changes in headspace gas concentrations for a closed system (initial atmosphere of air). Each data point represents the average of three replicate analyses.

\begin{tabular}{|c|c|c|c|c|c|c|}
\hline \multirow[b]{2}{*}{ Day } & \multicolumn{2}{|c|}{$\mathrm{O}_{2}(\%)$} & \multicolumn{2}{|c|}{$\mathrm{CO}_{2}(\%)$} & \multicolumn{2}{|c|}{$\mathrm{KO}_{2}\left(\mathrm{ml} \cdot \mathrm{kg}^{-1} \cdot \mathrm{h}^{-1}\right)$} \\
\hline & Run 1 & Run 2 & Run 1 & Run 2 & Run 1 & Run 2 \\
\hline 0 & 20.23 & 20.12 & 0.94 & 1.11 & 11.21 & 19.59 \\
\hline 1 & 19.43 & 18.96 & 1.76 & 2.27 & 9.34 & 11.12 \\
\hline 2 & 18.73 & 18.13 & 2.44 & 3.07 & 6.88 & 9.16 \\
\hline 3 & 18.12 & 17.37 & 3.04 & 3.85 & 7.37 & 8.04 \\
\hline 4 & 17.58 & 16.70 & 3.57 & 4.58 & 5.11 & 7.41 \\
\hline 5 & 17.15 & 16.13 & 3.98 & 5.10 & 5.12 & 7.61 \\
\hline 6 & 16.79 & 15.56 & 4.34 & 5.58 & 4.09 & 6.33 \\
\hline 7 & 16.33 & 15.03 & 4.77 & 6.11 & 7.56 & 6.15 \\
\hline 8 & 15.83 & & 5.18 & & 4.27 & \\
\hline 9 & 15.48 & & 5.49 & & 4.08 & \\
\hline 10 & 15.07 & & 5.98 & & 5.57 & \\
\hline 11 & 14.61 & & 6.49 & & 4.54 & \\
\hline 12 & 14.21 & & 6.88 & & 5.25 & \\
\hline 13 & 13.80 & & 7.34 & & 4.79 & \\
\hline 14 & 13.38 & & 7.70 & & 5.14 & \\
\hline
\end{tabular}

slightly more $\mathrm{O}_{2}$ than the calculations dictated so that the probability of anaerobiosis occurring in the packages would be reduced. Anaerobiosis is possible if the product is not maintained at refrigeration temperatures. Such a situation may occur in the retail environment. If the storage temperature increases, then the respiration rate of the tissue increases as does package permeability (Kader, 1987; Pascat, 1986). However, respiration rate may be more sensitive to temperature than package permeability and, therefore, $\mathrm{O}_{2}$ may not be supplied as quickly as it is consumed (Kader et al., 1989). It was found that a package size of $0.216 \times$ $0.254 \mathrm{~m}$ provided the ideal $\mathrm{O}_{2}$ permeance.

$\mathrm{P}^{\prime} \mathrm{O}_{2}$ needed to maintain $3 \% \mathrm{O}_{2}=\left(7.49 \mathrm{~cm}^{3} \cdot \mathrm{kg}^{-1} \cdot \mathrm{h}^{-1}\right)(0.1$ $\mathrm{kg}) /[(21278 \mathrm{~Pa}-3039 \mathrm{~Pa})(0.216 \mathrm{~m} \times 0.254 \mathrm{~m})]=0.00037$ $\mathrm{cm}^{3} \cdot \mathrm{m}^{-2} \cdot \mathrm{h}^{-1} \cdot \mathrm{Pa}^{-1}$.

Although $\mathrm{O}_{2}$ permeability was controlled, the plastic film used had an inherently high $\mathrm{CO}_{2}$ permeability. It was therefore expected that the $\mathrm{CO}_{2}$ initially flushed into the package would escape over time. As only $\mathrm{O}_{2}$ was controlled and $\mathrm{CO}_{2}$ was continually escaping, the package could only be deemed MA rather than CA.

Package headspace. The control samples (packaged in air) appeared to reach respiratory equilibrium within 2 days and maintained an atmosphere with about $2 \% \mathrm{CO}_{2}$ and $18 \%$ to $19 \% \mathrm{O}_{2}$. As expected, the MA packages lost $\mathrm{CO}_{2}$ over time (equilibrating at $2 \%$ to $4 \%$ ) and gained $\mathrm{O}_{2}$ (equilibrating at $7 \%$ to $11 \%$ ). The $\mathrm{O}_{2}$ concentration of trial I packages seemed to increase more than that of the trial II packages. A higher respiration rate in trial II may be the explanation. A possible cause for a higher respiration rate in trial II would be if the lettuce had sustained more damage in transit and/or processing (Rolle and Chism, 1987).

Significant trial $\times$ treatment interaction effects were found for several of the quality attributes considered. This indicated that the results of the two trials were sufficiently different that the trials should be treated separately. The specific differences between trials I and II will be discussed in greater detail in relation to the individual quality factors.

HunterLab L. The changes in HunterLab L value with time for treatments and control are shown in Fig. 1. No statistically significant differences in lightness were found between treatments and control in either trial I or II, although lightness values for the MAP samples were slightly better (higher) than for the control. A slight decrease in lightness was seen over time for all treatments in both trials. Aging lettuce develops red-brown stains due to phenolic oxidation and also decays due to senescence or bacterial proliferation (King and Bolin, 1989; Phan, 1987). These reactions cause a darkening of the tissue, which explains the drop in lightness value with time for all treatments. This corresponds well with the findings of Bolin and Huxsoll (1991), who studied color changes in iceberg lettuce. The slightly higher scores for the treated samples can be attributed to a preservative effect of the MAs (Kader, 1986). Of the three MAs, it was possible that $6 / 3$ was the most effective, particularly in trial II. However, it should be stressed that only slight differences were seen between samples and that there was not much change over time.

HunterLab $a$. The changes in HunterLab a values with time for treatments and control are shown in Fig. 2. A difference in this parameter was observed between trials I and II. In both trials there was a general increase in a values over time, but in trial II the treatments were significantly less red than the control. The increase in a values represented a shift from green to red (Hunter, 1975) and is likely due to the red discoloration resulting from phenolic oxidation (King and Bolin, 1989) and a loss of green color due to chlorophyll breakdown (Bolin and Huxsoll, 1991).

The magnitude of the change in a value over time was roughly the same for all treated samples in both trials but it was much greater for the control group in trial II versus trial I. It was postulated that the lettuce used in trial II may have sustained more damage in transit and processing and may also have been older due to the length of time spent in transit. This would result in a greater deterioration rate (Laties, 1978; Rolle and Chism, 1987) and is evidenced by the fact that, in trial II, all samples had higher respiration rates, passed the limit of saleability faster (discussed

Table 5. Coefficients of determination for enzymatic and linear fits.

\begin{tabular}{lcc}
\hline \hline Treatment & $R^{2}$ (enzymatic fit) & $R^{2}$ (linear fit) \\
\hline 6/3 (Run 1) & 0.07 & 0.57 \\
6/3 (Run 2) & 0.42 & 0.87 \\
10/3 (Run 1) & 0.17 & 0.66 \\
10/3 (Run 2) & 0.57 & 0.94 \\
14/3 (Run 1) & 0.08 & 0.44 \\
14/3 (Run 2) & 0.73 & 0.90 \\
\hline
\end{tabular}



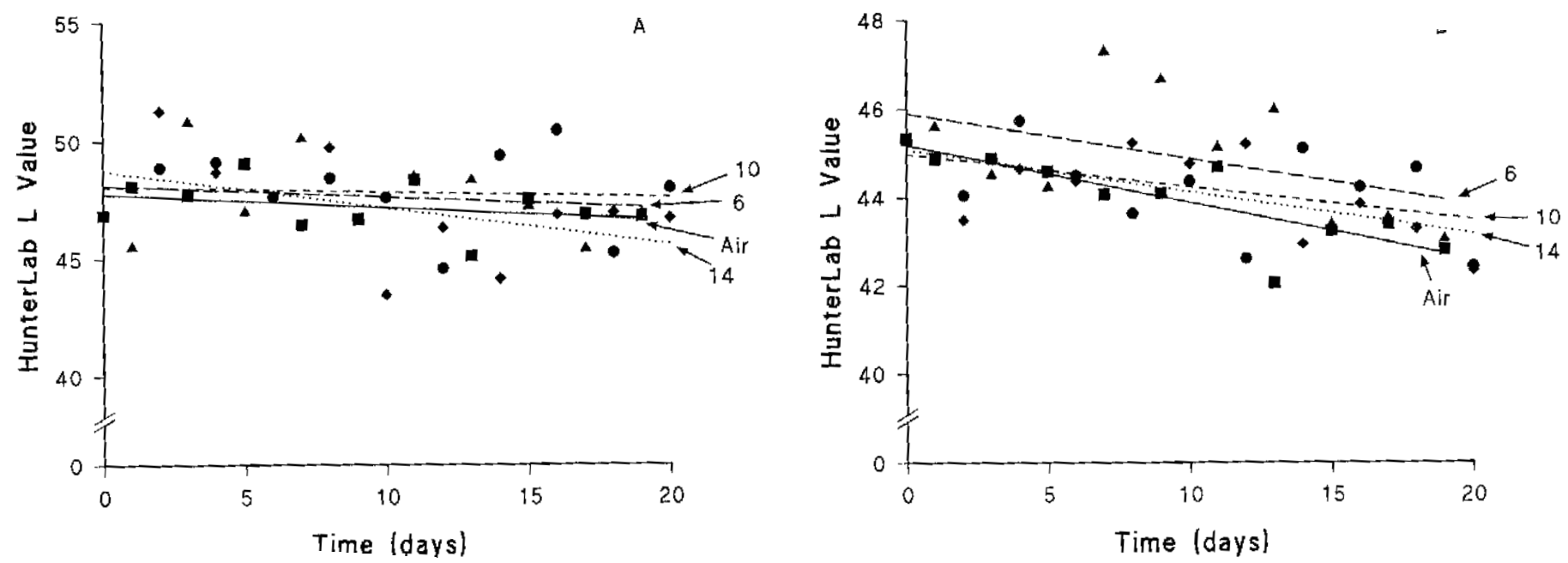

Fig. 1. Changes in HunterLab L value with storage time for modified-atmosphere-packaged and control samples in trial I (A) and trial II (B) (ם Air, $\mathbf{\Delta} 6 \% \mathrm{CO}_{2}, \bullet 10 \%$ $\left.\mathrm{CO}_{2}, \diamond 14 \% \mathrm{CO}_{2}\right)$.

later), had lower lightness values and higher a values relative to trial I. The increased effectiveness of the MAs in maintaining lower a values in trial II is likely due to the fact that the a value of the tissue was changing faster. In trial I, the a value did not change much, therefore the preservative effect of the MAs was not apparent.

As control samples appeared to have the highest incidence of red stain (see appearance ratings), they had the highest a values. MAs have been found to inhibit chlorophyll breakdown (Kader, 1986). This, as well as inhibition of phenolic oxidation, may contribute to the lower a values of the treated samples. There was no real trend suggesting which of the three MAs most effectively maintained the initial a value and therefore more effectively preserved the green color of the lettuce.

Microbiology. The growth profiles for pectinolytic bacteria on treatment and control samples are shown in Fig. 3. Great variability was found in the measurements, and the resulting confidence intervals were quite large. No statistically significant differences were found between treatments, and no treatment significantly inhibited the growth of pectinolytic bacteria relative to the control, concurring with the results of other studies (Barriga et al., 1991; Beuchat and Brackett, 1990; Hao and Brackett, 1993, 1994). Although no statistically significant differences were found between treatments, a trend was apparent, suggesting enhanced inhibition of pectinolytic bacteria growth with increasing amounts of $\mathrm{CO}_{2}$ in the storage atmosphere.

Low levels of lactic acid bacteria were found over the course of the experiment for all treatments and control. No counts higher than 2500 colony forming units (CFUs) were observed for any sample, and the number of lactic acid bacteria did not increase over time (data not shown). Erratic development of lactic acid bacteria and low counts concurs with the results of Barriga et al. (1991). According to theory, lactic acid bacteria prefer an anaerobic environment and, therefore, would be expected to be found in greater numbers on the 14/3 samples. This was not the case. In no sample did lactic acid bacteria growth become so pronounced that noticeable off odors were produced. It follows that lactic acid bacteria growth was not a problem, as the packages never became anaerobic, the noncontrol packages actually becoming more aerobic over time.

Appearance. As the visual quality ratings were provided by a single panelist, they are of questionable value. However, from a practical standpoint they are worth mentioning. According to the appearance scale modified from Kader et al. (1973), a rating of 5 represents the lower limit of sales appeal. In trials I and II, the control samples were given an average appearance rating of 5 on day 8 . Therefore, 8 days was estimated to be the shelf life of the control product.

A difference in appearance between treatments was evident in trial I (data not shown). By day 8, the appearance of all treatments was similar but better than the control. As time progressed, the deterioration in appearance of the control samples slowed and the appearance of the treated samples caught up. By day 20 only the 10/ 3 treatment looked better than the control. The appearance ratings were slightly different for trial II (data not shown). Once again, at the beginning and end of the experiment there was no difference between control and treatment groups. However, between days 4 and 17, all treatments were better than the control. None of the MAstored samples reached an appearance score of 5 before about 14 days. Overall, it was seen that all treatments were more effective than the control for maintaining the appearance of the lettuce, and of the three MAs, 10/3 seemed to be the best.

\section{General Discussion}

Over the course of the packaging portion of the experiment it was noted that there were two main factors that diminished the appearance of minimally processed romaine lettuce. These factors were the breakdown of the tissue structure (either internal or bacterial) as well as the development of red-brown discoloration due to phenolic oxidation. The preservative effect of the MAs can be attributed to an inhibition of internal decay as well as an inhibition of the action of phenolic enzymes such as polyphenol oxidase. Evidence for this comes from the inhibition of respiration by the MAs in the respiration study as well as the results of the color analysis. Bacterial breakdown was excluded as the MAs did not decrease the growth of pectinolytic bacteria.

The package designed as a result of the respiration study and subsequent mathematical analysis did a reasonable job of maintaining the desired headspace $\mathrm{O}_{2}$ concentration. The finding that the $\mathrm{O}_{2}$ level drifted somewhat above $3 \%$ is partly due to the error inherent in fitting a model to the respiration data. Also, to ensure against the development of anaerobiosis, some extra $\mathrm{O}_{2}$ was deliberately allowed into the package. Future work could involve experimentation with other mathematical models or respiration 

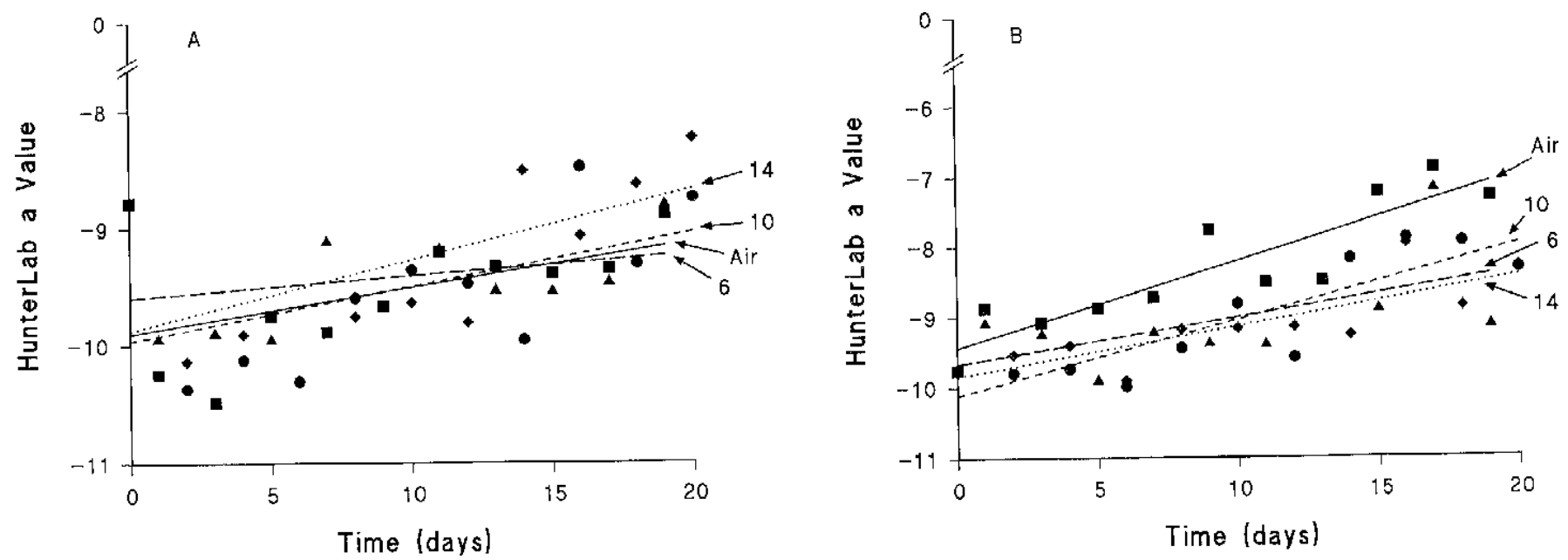

Fig. 2. Changes in HunterLab a value with storage time for modified-atmosphere-packaged and control samples in trial I (A) and trial II (B) ( $\left(\mathbf{\square}\right.$ Air, $\mathbf{A} 6 \% \mathrm{CO}_{2}, \bullet 10 \%$ $\left.\mathrm{CO}_{2}, \diamond 14 \% \mathrm{CO}_{2}\right)$.

systems (such as the two jar method; Lee et al., 1993, 1994; Yam et al., 1993) in an attempt to optimize the $\mathrm{O}_{2}$ permeability of the package so that it was maintained at $3 \%$. Maintaining a lower $\mathrm{O}_{2}$ concentration that is still in the aerobic region should improve the preservative effect of the package (Kader, 1986). The same would be true if a package could be developed that would allow the initial $\mathrm{O}_{2}$ and initial $\mathrm{CO}_{2}$ concentrations to be maintained.

Although the $\mathrm{O}_{2}$ level in the packages increased beyond $3 \%$, the MA packages were still significantly more effective than the air control in maintaining the quality of the minimally processed romaine lettuce. Storage under the MAs preserved overall appearance and reduced the development of staining attributable to phenolic oxidation. Although the growth of pectinolytic bacteria was not significantly retarded, the MA packages were no worse than the control. Of the three MAs tested, 10/3 was best, mainly due to an improved ability to maintain product appearance as assessed subjectively.

The beneficial effects of MAP on romaine lettuce agree with the findings of Aharoni and Ben Yehoshua (1973) and disagree with the findings of Lipton (1987), who found that MAP did not increase the shelf life of intact romaine lettuce heads. However, the gas concentrations used by Lipton were substantially different from those in this study. Looking at processed lettuce, McDonald et al. (1990) found MAP useful for chopped head lettuce, while Ballantyne et al. (1988) demonstrated the effectiveness of MAP on shredded head lettuce.

The shelf life of minimally processed romaine lettuce under the current processing and packaging routine is estimated at 8 days. Packaging the lettuce under a MA of $10 \% \mathrm{CO}_{2} / 3 \% \mathrm{O}_{2} / 87 \% \mathrm{~N}_{2}$ in the specially designed package appeared to retard deterioration enough to substantially extend the shelf life of the product (under proper temperature control). This can be viewed as a success, as it would allow greater product distribution and lower product turnover. However, since only the growth of pectinolytic and lactic acid bacteria was studied, future work should assess whether MAP has any influence on the growth of pathogenic bacteria.

\section{Literature Cited}

Aharoni, N. and S. Ben-Yehoshua. 1973. Delaying deterioration of romaine lettuce by vacuum cooling and modified atmosphere produced in polyethylene packages. J. Amer. Soc. Hort. Sci. 98:464-468.

Andrich, G., R. Fiorentini, A. Tuci, A. Zinnai, and G. Sommovigo. 1991. A tentative model to describe the respiration of stored apples. J. Amer.

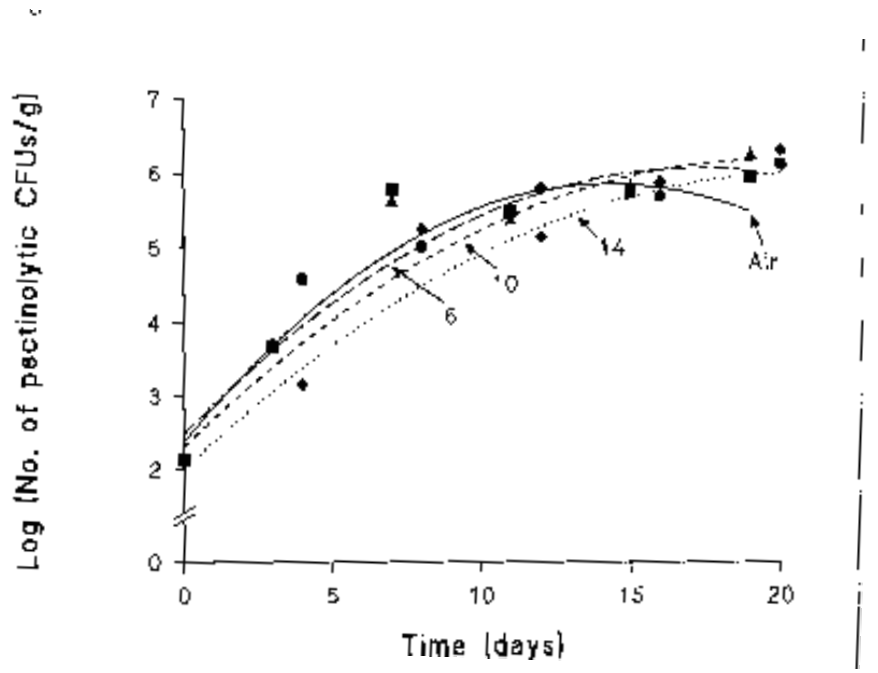

Fig. 3. Growth of pectinolytic bacteria with storage time in modified-atmospherepackaged and control samples ( $\mathbf{\square}$ Air, $\mathbf{\Delta} 6 \% \mathrm{CO}_{2}, \bigcirc 10 \% \mathrm{CO}_{2}, \diamond 14 \% \mathrm{CO}_{2}$ ).

Soc. Hort. Sci. 116:478-481.

Ballantyne, A., R. Stark, and J.D. Selman. 1988. Modified atmosphere packaging of shredded lettuce. Intl. J. Food Sci. Technol. 23:267-274.

Barriga, M.I., G. Trachy, C. Willemot, and R.E. Simard. 1991. Microbial changes in shredded lettuce stored under controlled atmospheres. J. Food Sci. 56:1586-1599.

Beuchat, L.R. and R.E. Brackett. 1990. Survival and growth of Listeria monocytogenes on lettuce as influenced by shredding, chlorine treatment, modified atmosphere packaging and temperature. J. Food Sci. 55:755-758.

Bolin,H.R. and C.C. Huxsoll. 1991. Effect of preparation procedures and storage parameters on quality retention of salad cut lettuce. J. Food Sci. 56:60-67.

Brecht, P.E. 1980. Use of controlled atmospheres to retard deterioration of produce. Food Technol. 34(3):45-50.

Cameron, A.C., R.M. Beaudry, N.H. Banks, and M.V. Yelanich. 1994. Modified-atmosphere packaging of blueberry fruit: Modelling respiration and package oxygen partial pressures as a function of temperature. J. Amer. Soc. Hort. Sci. 119:534-539.

Cameron, A.C., W. Boylan-Pett, and J. Lee. 1989. Design of modified atmosphere packaging systems: Modelling oxygen concentrations within sealed packages of tomato fruits. J. Food Sci. 54:1413-1416, 1421.

Garg, N., J.J. Churey, and D.F. Splittstoesser. 1990. Effect of processing conditions on the microflora of fresh cut vegetables. J. Food Prot. 53:701-703. 
Gong, S. and K.A. Corey. 1994. Predicting steady-state oxygen concentrations in modified-atmosphere packages of tomatoes. J. Amer. Soc. Hort. Sci. 119:546-550.

Haggar, P.E., D.S. Lee, and K.L. Yam. 1992. Application of an enzyme kinetics based respiration model to closed system experiments for fresh produce. J. Food Proc. Eng. 15:143-157.

Hankin, L., M. Zucker, and D.C. Sands. 1971. Improved solid medium for the detection and enumeration of pectolytic bacteria. Appl. Microbiol. 22:205-209.

Hao, Y.Y. and R.E. Brackett. 1993. Influence of modified atmosphere on growth of vegetable spoilage bacteria in media. J. Food Prot. 6:223-228.

Hao, Y.Y. and R.E. Brackett. 1994. Pectinase activity of vegetable spoilage bacteria in modified atmosphere. J. Food Sci. 59:175-178.

Hayakawa, K., Y.S. Henig, and S.G. Gilbert. 1975. Formulae for predicting gas exchange of fresh produce in polymeric film package. J. Food Sci. 40:186-191.

Henig, Y.S. and S.G. Gilbert. 1975. Computer analysis of the variables affecting respiration and quality of produce packaged in polymeric films. J. Food Sci. 40:1033-1035.

Herner, R.C. 1987. High carbon dioxide effects on plant organs, p. 239253. In: J. Weichmann (ed.). Postharvest physiology of vegetables. Marcel Dekker, New York.

Hunter, R.S. 1975. The measurement of appearance. Wiley, New York.

Joles, D.W., A.C. Cameron, A. Shirazi, P.D. Petracek, and R.M. Beaudry. 1994. Modified-atmosphere packaging of 'heritage' red raspberry fruit: Respiratory response to reduced oxygen, enhanced carbon dioxide, and temperature. J. Amer. Soc. Hort. Sci. 119:540-545.

Jurin, V. and M. Karel. 1963. Studies on control of respiration of McIntosh apples by packaging methods. Food Technol. 17(6):104-108.

Kader, A.A. 1986. Biochemical and physiological basis for effects of controlled and modified atmospheres on fruits and vegetables. Food Technol. 40(5):99-104.

Kader, A.A. 1987. Respiration and gas exchange of vegetables, p. 25-43. In: J. Weichmann (ed.). Postharvest physiology of vegetables. Marcel Dekker, New York.

Kader, A.A., W.J. Lipton, and L.L. Morris. 1973. Systems for scoring quality of harvested lettuce. HortScience 8:408-409.

Kader, A.A., D. Zagory, and E. Kerbel. 1989. Modified atmosphere packaging of fruits and vegetables. CRC Crit. Rev. Food Sci. Nutr. 28:1-30.

Kays, S.J. 1991. Postharvest physiology of perishable plant products. Van Nostrand Reinhold, New York. p. 120-122.

King, Jr., A.D. and H.R. Bolin. 1989. Physiological and microbiological storage stability of minimally processed fruits and vegetables. Food Technol. 43(2):132-135.

Laties, G.G. 1978. The development and control of respiratory pathways in slices of plant storage organs, p. 421-466. In: G. Kahl (ed.). Biochemistry of wounded plant tissues. Walter de Gruyter, Berlin, Germany.

Lee, D.S., P.E. Haggar, J. Lee, and K.L. Yam. 1991. Model for fresh produce respiration in modified atmospheres based on principles of enzyme kinetics. J. Food Sci. 56:1580-1585.

Lee, D.S., K.S. Lee, I.S. Park, and K.L. Yam. 1993. Measuring respiration characteristics of low $\mathrm{CO}_{2}$ tolerance produces for designing modified atmosphere packing of fresh produce. Intl. Workshop Eng. Properties of Foods, Bangkok, Thailand, 20-22 Sept.

Lee, J.L. 1986. The design of controlled or modified packaging systems for fresh produce, p. 157-169. In: J.I. Gray, B.R. Harte, and J. Miltz (eds.). Food product-package compatibility. Technomic Publishing, Lancaster, $\mathrm{Pa}$.

Lee, K.S., K.L. Woo, and D.S. Lee. 1994. Modified atmosphere packaging for green chili peppers. Pkg. Technol. Sci. 7:51-58.

Lipton, W.J. 1987. Carbon dioxide induced injury of romaine lettuce stored in controlled atmospheres. HortScience 22:461-463.

Lopez-Briones, G., P. Varoquaux, G. Bureau, and B. Pascat. 1993. Modified atmosphere packaging of common mushroom. Intl. J. Food Sci. Technol. 28:57-68.

McDonald, R.E., L.A. Risse, and C.R. Barmore. 1990. Bagging chopped lettuce in selected permeability films. HortScience 25:671-673.

Neter, J., W. Wasserman, and M.H. Kutner. 1990. Applied linear statistical models. Richard D. Irwin, Homewood, Ill.

Pascat, B. 1986. Study of some factors affecting permeability, p. 7-24. In: M. Mathlouthi (ed.). Food packaging and preservation: Theory and practice. Elsevier, New York.

Phan, C.T. 1987. Biochemical and physical changes during the harvest period, p. 9-22. In: J. Weichmann (ed.). Postharvest physiology of vegetables. Marcel Dekker, New York.

Priepke, P.E., L.S. Wei, and A.I. Nelson. 1976. Refrigerated storage of prepackaged salad vegetables. J. Food Sci. 41:379-382.

Rolle, R.S. and G.W. Chism, III. 1987. Physiological consequences of minimally processed fruits and vegetables. J. Food Qual. 10:157-177.

Weichmann, J. 1987. Low oxygen effects, p. 231-237. In: J. Weichmann (ed.). Postharvest physiology of vegetables. Marcel Dekker, New York.

Yam, K.L., P.E. Haggar, and D.S. Lee. 1993. Modelling respiration of low $\mathrm{CO}_{2}$ tolerance produce using a closed system experiment. Food Biotechnol. 2:22-25. 